\title{
It's good to talk in the Digital Age
}

Nicky Garsten

University of Greenwich

\begin{abstract}
Our millennial students may, at times, feel apprehensive about talking face to face or on the phone. Whilst the development of digital skills is crucial in our connected age, let's not forget about the importance of verbal communications.
\end{abstract}

The media can portray youngsters as digitally obsessed, detached and inarticulate. For instance, in the BBC comedy 'W1A' the intern, Will Humphries (played by Hugh Skinner), "spends most of his time wandering round plugged into his MP3 player trying to find out what he's supposed to be doing" (BBC, 2017). He rarely initiates a conversation. When he responds it is usually with the monosyllable 'cool'. This portrayal certainly isn't my experience of our lively student population, many of whom secure fabulous work experience opportunities for themselves. However, the characterisation does make a point.

Talking isn't always students' first choice of communication with co-workers on an internship. Verbal reticence was identified at a recent conference bringing together employers and academics at Birmingham City University. ${ }^{1}$ Head-phoned student interns, reported a disappointed practitioner, were more comfortable communicating silently on screen than speaking face to face to colleagues or clients. What students needed, she said, was to be taught verbal communication skills. Similarly, lecturer Sam Pidoux noted that students often preferred to email lecturers rather than to speak to them during office hours. Emails were not only convenient but also relieved undergraduates of their anxiety about broaching potentially awkward conversations face to face. Pidoux believes that students need to understand that a normal part of conversing is feeling stress when broaching awkward topics.

"Millennials are digital omnivores" according to millennial marketing specialist Josie Baik (2016). Their online savviness is a strength in an age where digital developments have the potential to unlock $\$ 100$ trillion (World Economic Forum, 2017). Indeed, digital transformation, according to the World Economic Forum (ibid., p. 2), "has the immense potential to change consumer lives, create value for business and unlock broader societal benefits." According to PwC research, two thirds of UK chief executives surveyed report problems in recruiting people with digital skills (Ellis, 2017). Never has the need to teach our students digital skills been more acute.

Yet, as outlined earlier, there is also still a need for the soft skill of verbal communication. The ability to communicate verbally, inside and outside an organisation, is in the top three skills employers most want in graduates, according to Forbes (Adams, 2014). Nevertheless, our students of this generation 'hate' talking on the phone because they are 'more

\footnotetext{
${ }^{1}$ Mind the PR Gap 2017- bringing together research and practice. $12^{\text {th }}$ July. Birmingham City University.
} 
comfortable' with texts, emails and messaging, all of which give them the opportunity to pick their words (Alton, 2017).

When we encourage our students to speak, there is no doubt that we need to adapt to our 'digital natives' (Prensky, 2001), even if in small ways. It's a start just being aware that for some students, in some situations, talking may be stressful. We can bear this in mind when we expect students to participate in academic life, be it verbally contributing to seminar sessions or taking advantage to talk to their tutors in office hours. Since seminars are integral to university teaching in many institutions and countries, do we organise seating so that students can look at each other when speaking? Do we show interest and curiosity when students tell us things that we don't know? Do we have a rule that no question is 'stupid', given that, if one person in a group articulates something, it is likely that others are thinking it too? Lecturers often offer office hours. I was startled when a friend's daughter observed that she had initially felt, in her first year, that her lecturers didn't really want to see her during their office hours. How do we greet students when they knock at our doors? Counsellors refer to the importance of eye contact at entry, to help facilitate relationship depth. Furthermore, we can convene special drop-in surgeries - for specific assessments that convey the message that it's okay to have further questions about assignments and it's important to start work early on these tests.

We can also support networking events for our students by inviting alumni and other professionals, who can help them develop their professional networks. In preparation for these events, we can coach them. Introverts for instance, can learn from the excellent guidance of Cain (2012) and Zach (2014). The key point for them to learn is that both introverts and extroverts can be great networkers.

Students are expected now to enter the workforce with digital, writing and verbal skills. This means that we need to be mindful of teaching all these skills. I've never met a student like the character, Will Humphries. We need to talk to our students to ensure that we never do.

\section{Reference list}

Adams, S. (2014) 'The 10 Skills Employers Most Want In 2015 Graduates.' Available at: https://www.forbes.com/sites/susanadams/2014/11/12/the-10-skills-employers-most-want-in2015-graduates/\#6f13d1132511 (Accessed: 31 October 2017).

Alton, L. (2017) 'Phone Calls, Texts Or Email? Here's How Millennials Prefer To Communicate.' Forbes.com. Available at: https://www.forbes.com/sites/larryalton/2017/05/11/how-do-millennials-prefer-tocommunicate/\#2384d0966d6f. (Accessed: 31 October 2017).

Baik, J. (2016) How enterprises can optimize mobile apps for millennials. Mobile Business Insights. Available at: https://mobilebusinessinsights.com/2016/01/how-enterprises-canoptimize-mobile-apps-for-millennials. (Accessed: 31 October 2017). 
BBC (2017) Staff profiles: Will Humphries. Available at:

http://www.bbc.co.uk/programmes/profiles/2ZSy582ZFV8gDyQblVw6twT/will-humphries.

(Accessed: 31 October 2017).

Cain, S. (2012) Quiet: the Power of Introverts in a World that Can't StropTalking. Location: Sage.

Ellis, K. (2017) 'PWC proposes new way of overcoming shortage of technology skills.' The Times. Available at: https://www.thetimes.co.uk/article/how-to-fill-gaping-skills-gap-intechnology-riczwplk5. (Accessed: 31 October 2017).

Prensky, M. (2001) 'Digital Natives Digital Immigrants.' Available at:

http://www.marcprensky.com/writing/Prensky\%20-

\%20Digital\%20Natives, \%20Digital\%20Immigrants\%20-\%20Part1.pdf (Accessed: 31 October 2017).

World Economic Forum (Year) Digital Transformation Initiative in collaboration with Accenture. Available at: http://reports.weforum.org/digital-transformation/wpcontent/blogs.dir/94/mp/files/pages/files/170328-dti-executive-summary-slideshare.pdf (Accessed: 31 October 2017).

Zach (2014) Networking for People who Hate Networking. San Francisco: Berrett-Koehler. 